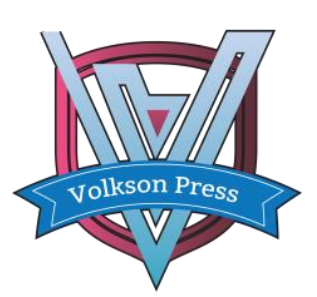

Contents List available at VOLKSON PRESS

Economics \& Management Innovations(EMI)

DOI : http://doi.org/10.26480/icemi.01.2017.126.127

\title{
On the Construction and Management Mode of Teaching Staff in Higher Vocational Colleges
}

\author{
Zhang kai*, Xiuzhi Wei \\ Ji Ning Polytechnic \\ *email: sdjnzk@foxmail.com \\ This is an open access article distributed under the Creative Commons Attribution License, which permits unrestricted use, distribution, and reproduction in any \\ medium, provided the original work is properly cited.
}

\section{ARTICLE DETAILS}

\section{Article History:}

Received 02 october 2017

Accepted 06 october 2017

Available online 11 october 2017

Keywords:

Vocational colleges; Teachers;

Talent; Teaching quality.

\section{ABSTRACT}

\begin{abstract}
In recent years, higher vocational colleges have been developing rapidly in our country. The quality of teachers in vocational colleges has a direct impact on the teaching level of higher vocational education. However, there are still many problems in the construction of teachers in higher vocational colleges, In the management model also need to be improved, to this end, we must continue to strengthen the construction of faculty of vocational colleges, and actively change the management needs of social development is not suitable for the pattern and has been oldfashioned teaching concept. We should pay full attention to the concept of teacher-oriented, the use of scientific and rational personnel to introduce the system, improve the teacher assessment system, and strive to improve the overall level of teachers in vocational colleges and institutions to promote the development of higher vocational education.
\end{abstract}

\section{Introduction}

Higher vocational education also occupies a very large position in the whole education system. It is also an indispensable part in our country's higher education. It plays a very important role in our country's social construction and economic development, and also conforms to the national policy Regulations, and conform to the social development of the demand for the popularization of higher education. Since the implementation of the document on the deepening of education reform, the development of vocational and technical education in China has entered the fast lane, the number of vocational and technical institutions is increasing, for the community to cultivate a large number of applied talents. The level of the overall level of the teaching staff will directly affect the quality of teaching in higher vocational colleges and the cultivation of talent level. The construction work and management of the teaching staff in higher vocational colleges are also the daily work of higher vocational colleges In a very important part. In order to meet the needs of the modern construction of the application of talent, should continue to increase the "double teacher" teacher force the introduction and training, to build a higher level of full-time, part-time teachers. The use of more scientific management of higher vocational colleges and more humane management system, so that China's vocational education to achieve a qualitative leap.

\section{Problems of teachers construction}

\subsection{The structural aspects of the faculty}

At present, the development of higher vocational education in our country is already mature, and the structure of the faculty is improving. However, there are still many problems. From the age structure of the full-time teachers in higher vocational colleges, the teachers aged 35 and under can To $50 \%$ of the total number of teachers, vocational colleges, young teachers have become the main force of teaching, but from the historical and cultural accumulation to analyze, more than 50 years old the number of outstanding professors, can not achieve the old professor of young teachers And the help of the role of vocational colleges, teachers, the core strengths of the lack of senior titles above the number of teachers less, and the proportion of senior titles is also very unsatisfactory, from the teacher's qualifications to analyze, in vocational colleges Very lack of excellent doctorate with a doctorate, with a bachelor's degree teachers still living as the main force, with the master's degree and above the number of teachers can not meet the normal teaching needs. From the classification of teachers to analyze the number of public basic teachers can account for about 30\%, professional teachers can account for about
$70 \%$, the proportion of public teachers is low. Higher vocational colleges also exist the problem of large mobility of teachers, the ability to attract highly educated talents is not strong, lack of expert teachers, and there are more excellent teachers lost the phenomenon. Through the investigation and analysis of the structure of teachers' qualifications in higher vocational colleges in our country, the following statistics are obtained.

Table 1 Higher Vocational Education Statistics Table

\begin{tabular}{|l|l|l|l|l|}
\hline & Doctor & $\begin{array}{l}\text { Master's } \\
\text { degree }\end{array}$ & $\begin{array}{l}\text { Undergrad } \\
\text { uate }\end{array}$ & College \\
\hline Is advanced & 15 & 80 & 7 & 0 \\
\hline $\begin{array}{l}\text { Deputy } \\
\text { senior }\end{array}$ & 5 & 700 & 865 & 8 \\
\hline Intermediate & 0 & 215 & 1763 & 59 \\
\hline Primary & 0 & 102 & 1157 & 33 \\
\hline No title & 0 & 10 & 307 & 22 \\
\hline Total & 20 & 1107 & 4099 & 122 \\
\hline
\end{tabular}

\subsection{The quality of the faculty is the problem}

Higher vocational education often can not be teaching content and practice the effective combination of the phenomenon, teachers are more inclined to impart a theoretical knowledge, lost the characteristics of vocational education. The main goal of higher vocational education the technical, managerial and service talents in the frontline work need to focus on practice and adhere to the principle of simultaneous theory and practice in the process of teaching. And vocational colleges ignore the advantages of their own professional research results, can not make full use of their own experimental internship equipment to complete the task of scientific research at all levels, through a survey of institutions to obtain scientific research situation statistics as follows.

Table 2. A technical college five years of scientific research statistics

\begin{tabular}{|l|c|c|c|c|c|}
\hline & 2012 & 2013 & 2014 & 2015 & 2016 \\
\hline $\begin{array}{l}\text { National } \\
\text { level }\end{array}$ & 11 & 4 & 8 & 18 & 41 \\
\hline Provincial & 71 & 65 & 49 & 44 & 229 \\
\hline City level & 25 & 39 & 88 & 77 & 229 \\
\hline Total & 107 & 108 & 145 & 139 & 499 \\
\hline
\end{tabular}




\subsection{The problems of the management of the faculty}

In the higher vocational colleges, there are not enough scientific phenomena in the planning of the faculty, and the planning plan can not be implemented in time and effectively. In the process of recruiting and hiring teachers, the propaganda is not enough, the recruitment requirements are not strict enough, and the teachers' System. The teacher's professional level and teaching ability did not develop a regular training program, the teacher's enthusiasm can not be effectively motivated, institutions of higher learning managers also exist management experience, management concept behind the phenomenon.

3. Countermeasure of Construction and Management Mode of Teaching Staff in Higher Vocational Colleges

\subsection{Optimize the structure of the faculty}

Facing the problem of unbalanced teaching staff in higher vocational colleges, we should formulate more preferential policies to attract more high-level talents to join the teaching of vocational colleges. We should pay more attention to the optimization of the structure of teachers, Young teachers at the same time, but also to employ some experienced old teachers, the formation of old teachers to lead and help the pattern of new teachers. Vocational colleges to actively develop teacher training planning, from the policy to give excellent teachers a certain degree of concessions and encouragement, so that the teacher's title structure is more reasonable, to actively introduce the production experience of the backbone of the technical staff to the school or hired as part-time Teachers, so that the structure of teachers more reasonable.

\subsection{Improve the overall quality of the faculty}

Vocational institutions and the strength of the research institutions are still far behind the gap, and vocational institutions of research funding, teachers, welfare system and promotion channels are not and undergraduate institutions, which requires the state to introduce more tend to occupation Institutions of the policy, vocational institutions themselves should also actively reform the appointment system, using a variety of ways to attract talent, we must pay attention to the training of teachers have been employed to allow teachers to teach new teachers teaching experience, but also send new teachers to other strength Strong institutions to study and study, using both internal and external ways to improve the level of vocational and technical college teachers teaching. At the same time, it is necessary to organize the internal exchange of new teachers, through mutual learning, to promote teachers to obtain more subject knowledge. The use of existing cooperative enterprises, the teachers into the enterprise to practice and enhance the practical ability of teachers, so that teachers can better grasp the current professional and technical development, improve the overall quality of teachers.

\subsection{The management of the teaching staff}

The grassroots leaders of vocational colleges can choose from ordinary teachers with high teaching ability. At the same time, we must constantly reform the supporting measures, improve the vocational and technical college teachers welfare system, effectively promote the introduction of high-level talent, through a variety of ways, so that the leadership of university managers more professional. And also pay attention to the urgent need for teachers of the reserve work, give full play to the autonomy of personnel in vocational colleges, improve the title evaluation system, so that teachers have a high teaching ability and teaching initiative.

\section{Conclusions}

In the context of the country's vigorous development of higher vocational education, the number of higher vocational colleges has increased very rapidly, and the teaching level of cultivating first-line skilled workers has also been greatly developed. However, there are still many problems. This paper analyzes the problems of teacher construction and puts forward the solution, so as to promote the healthy and orderly development of the construction and management of teachers in higher vocational colleges in order to promote the construction and management of teachers in higher vocational colleges.

\section{References}

[1] Tong Fuyong, the current problems in the ranks of teachers and countermeasures [J]. Wenzhou: Journal of Wenzhou University, 2015. [2] Xu Wenfen, analysis of vocational colleges in the construction of teachers in the problems and countermeasures, Hubei: social science [J] .2016 .25 (3).

[3] Zhang Ling, talk about higher vocational college staff management "teacher-oriented", Liaoning: Journal of Education .2014.

[4] Liu Baobin, vocational school "double teacher" teacher team building thinking, Hubei: social science [J] .2015.16 (4). 